\title{
Sistem Pakar Diagnosa Penyakit Skizofrenia dengan Forward Chaining dan Bayesian Network
}

\author{
Abu Salam ${ }^{1}$, Junta Zeniarja ${ }^{2}$, Riyan Ardiansyah ${ }^{3}$ \\ Fakultas Ilmu Komputer, Universitas Dian Nuswantoro \\ Jl. Nakula 5 - 11, Semarang, 50131, (024) 3517261 \\ Email : abu.salam@dsn.dinus.ac.id, junta@dsn.dinus.ac.id, 111201408394@mhs.dinus.ac.id
}

Diterima: 18 Januari 2021; Direvisi: 13 April 2021; Disetujui: 06 Mei 2021

\begin{abstract}
Abstrak
Skizofrenia merupakan gangguan kesehatan jiwa yang menjadi permasalahan masyarakat yang sangat penting serta harus memperoleh perhatian dari pemerintah. Hasil Riset Kesehatan Dasar (RisKesDas) pada tahun 2013 di negara Indonesia terdapat 1,7 dari 1000 warga atau kurang lebih 400.000 orang yang menderita penyakit Skizofrenia. Kurang meratanya tenaga kesehatan di bidang kejiwaan memperburuk penanganan yang seharusnya dapat segera dilakukan. Pada penelitian ini dibangun sebuah sistem pendukung keputusan diagnosa penyakit skizofrenia dengan forward chaining dan bayesian network sebagai aplikasi yang dapat mendiagnosa penyakit skizofrenia dengan lebih spesifik dan dapat digunakan oleh petugas kesehatan pada puskesmas. Metode forward chaining digunakan untuk mendapatkan sebuah kesimpulan dari gejala-gejala skizofrenia yang dimiliki oleh pasien dan bayesian network untuk menghitung seberapa akurat suatu sistem pakar tersebut mengidentifikasi suatu masalah. Proses konsultasi pakar dengan dokter spesialis jiwa di Rumah Sakir Umum Daerah Kajen untuk proses analisa kebutuhan data jenis penyakit, gejala penyakit dan hubungan penyakit dengan gejala. Proses pengujian fungsionalitas sistem pakar ini berjalan dengan baik dengan tingkat akurasi tiap-tiap gejala mendapatkan hasil diatas $80 \%$.
\end{abstract}

Kata kunci : sistem pakar, skizofrenia, forward chaining, bayesian network

\begin{abstract}
Schizophrenia is a mental health disorder that is a very important community problem and must get attention from the government. Results of Basic Health Research (RisKesDas) 2013 in Indonesia there were 1.7 out of 1000 residents or approximately 400,000 people suffering from schizophrenia. The lack of equal distribution of health workers in the psychiatric sector has worsened the handling that could have been carried out immediately. In this study, a decision support system for diagnosing schizophrenia was built with forward chaining and bayesian networks as applications that can diagnose schizophrenia more specifically and can be used by health workers at the health center. The forward chaining method is used to get a conclusion from the symptoms of schizophrenia that the patient has and the bayesian network to calculate how accurately an expert system identifies a problem. The process of expert consultation with a psychiatrist at the Kajen Regional General Sakir Hospital is for the process of analyzing the need for data on types of disease, symptoms of disease and the relationship of disease to symptoms. The process of testing the functionality of this expert system goes well with an accuracy level of each symptom getting results above $80 \%$.
\end{abstract}

Keywords : expert system, schizophrenia, forward chaining, bayesian network. 


\section{PENDAHULUAN}

Kesehatan Jiwa merupakan permasalahan masyarakat yang sangat penting serta harus memperoleh perhatian dari pihak pemerintah pusat maupun daerah dan juga dari seluruh masyarakat [1], [3]. Permasalahan penyakit yang menyangkut kesehatan jiwa di tanah air cukup besar. Terdapat berbagai macam penyakit gangguan jiwa, diantaranya gangguan kecemasan (misal phobia), gangguan kepribadian (misal antisosial), gangguan suasana hati (misal gangguan bipolar), gangguan psikotik (misal skizofrenia) dan masih banyak lagi. Menurut Kementrian Kesehatan Republik Indonesia, berdasarkan hasil dari Riset Kesehatan Dasar (RisKesDas) pada tahun 2013 di Negara Indonesia terdapat 1,7 per 1000 warga atau kurang lebih 400.000 orang yang menderita penyakit skizofrenia [2], [4], [5].

Skizofrenia merupakan gangguan jiwa pada proses berpikir yang disharmoni (retak atau pecah) antara proses piker, emosional, keinginan, psikomotor disertai distorsi kenyataan yang disebabkan oleh waham (delusi), halusinasi, asosiasi terbagi hingga muncul inkoherensi, baik laki-laki maupun perempuan dapat mengidap penyakit skizofrenia [6],[7],[8]. Usia yang paling rentan terkena penyakit ini adalah sekitar usia 15 tahun hingga 35 tahun. Apabila terdapat kerabat atau orang terdekat menunjukan gejala skizofrenia, lebih baik segera dikonsultasikan kepada dokter atau puskesmas terdekat. Karena apabila penyakit ini terdeteksi dini, maka penderita peluang untuk sembuh lebih besar [9].

Sistem pakar mampu menemukan solusi sebagaimana yang dikerjakan oleh seorang pakar, seperti memberikan diagnosis dan saran pengobatan penderita schizophrenia [10], dalam perkembangannya terdapat beberapa metode yang dapat digunakan dalam sistem pakar, antara lain yaitu forward chaining dan bayesian network. [11], [12]. Dimana forward chaining rnerupakan metode inferensi dari sistem pakar yang dapat mengerjakan penalaran dari suatu masalah kepada solusi, apabila klausa premis sesuai dengan situasi (bernilai TRUE), maka proses akan menyatakan konklusi [13], selain metode Forward chaining digunakan untuk memperhitungkan datangnya bermacam-macam gejala yang digunakan untuk mempermudah dalam mendiagnosis penyakit serta mengingat akan adanya gejala yang tidak pasti, maka metode Bayesian Network juga dapat di terapkan dalam membantu mendiagnosis penyakit skizofrenia. Bayesian network merupakan sebuah model grafis hubungan probabilistic antara satu set variabel. Metode ini juga mempunyai nilai akurasi yang bagus serta dapat mengurangi kompleksitas bila dibandingkan dengan naive bayes. Hal tersebut dikarenakan tiap-tiap penyakit mempunyai gejala yang berbeda yang tiap variabelnya tidak saling bebas [14], [15].

Penelitian yang dilakukan adalah membuat sistem pakar untuk mendiagnosa penyakit skizofrenia berbasis web menggunakan Forward Chaining dan Bayesian Network, diharapkan dapat membantu pihak tenaga kerja kesehatan ketika mendiagnosa dengan lebih mudah sehingga pasien dapat memperoleh hasil diagnosa disertai dengan keterangan dan penanganan yang tepat dan cepat.

\section{METODE PENELITIAN}

Tahapan proses penelitian yang dilakukan dijelaskan dalam kerangka pemikiran pada gambar 1. Dan berikut langkah-langkah yang akan dilakukan dalam proses penyelesaiaanya.

\subsection{Deteksi Dini Skizofrenia}

Berdasarkan penelitian yang dilakukan di Puskesmas Mojo diketahui bahwa petugas kesehatan masih sulit mendeteksi penyakit skizofrenia secara benar. Deteksi dini hanya mengandalkan proses pemeriksaan oleh dokter yang membidangi dan bahkan harus dilakukan rujukan terlebih dahulu ke Rumah Sakit yang memiliki Dokter Spesialis Jiwa.

\subsection{Pengumpulan Data}


Peneliti mendapatkan data pasien skizofrenia dari Puskesmas Mojo, kemudian proses wawancara dengan dokter spesialis jiwa di Rumah Sakir Umum Daerah Kajen untuk memastikan data jenis penyakit, gejala penyakit dan hubungan penyakit dengan gejala sebagai proses requirement. Diperoleh beberapa data nama penyakit, gejala-gejala dan hubungan penyakit dengan gejala-gejala yang ditampilkan pada tabel 1 dan tabel 2.

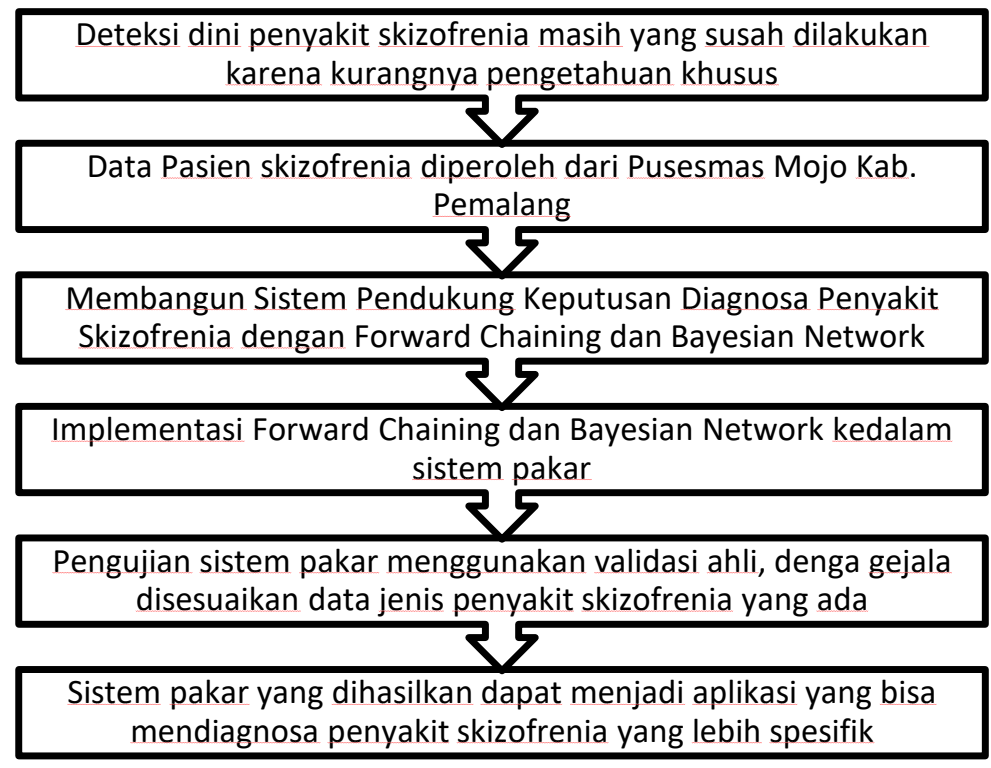

Gambar 1. Kerangka Pemikiran

Tabel 1. Data Kategori penyakit skizofrenia

\begin{tabular}{cl}
\hline Kode Penyakit & Nama Penyakit \\
\hline SF1 & Schizoaffective Disorder \\
SF2 & Schizofrenia Katatonik \\
SF3 & Schizofrenia Hebephrenia \\
SF4 & Childhood Onset \\
SF5 & Paranoid \\
SF6 & Undifferentiated Schizofrenia \\
SF7 & Schizofrenia Residual \\
\hline
\end{tabular}

Tabel 2. Data Gejala Penyakit Gangguan Kejiwaan

\begin{tabular}{cl}
\hline Kode Gejala & \\
\hline GSF1 & Hilang nafsu makan \\
GSF2 & Berat badan turun atau naik tanpa disengaja \\
GSF3 & Perubahan kebiasaan tidur (menjadi jarang tidur atau tidak tidur sama sekali) \\
GSF4 & Gelisah \\
GSF5 & Hilang energi \\
GSF6 & Hilang minat pada hal-hal yang biasa dilakukan \\
GSF7 & Merasa diri tidak berarti dan tidak punya harapan \\
GSF8 & Perasaan bersalah atau menyalahkan diri sendiri \\
GSF9 & Kesulitan berpikir dan berkonsentrasi \\
GSF10 & Memikirkan kematian atau bunuh diri \\
GSF11 & Terlihat lebih aktif dari biasanya \\
GSF12 & Bicara lebih cepat atau lebih cerewet \\
GSF13 & Banyak pikiran berseliwer di kepala \\
GSF14 & Tidak merasa perlu tidur \\
GSF15 & Gelisah, tidak sabaran \\
\hline
\end{tabular}




\subsection{Aplikasi Sistem Pakar}

Dari tahapan requirement dan data yang didapatkan sebagai dasar dalam proses penyusunan aplikasi sistem pakar, dalam penelitian ini peneliti menggunakan metode Forward Chaining dan Bayesian Sistem untuk membangun sistem pakar yang digunakan untuk diagnosa penyakit skizofrenia di Puskesmas mojo. Metode Forward Chaining digunakan untuk mencari rule apakah pasien terdiagnosa penyakit skizofrenia, sedangkan metode Bayesian Network di gunakan untuk mengetahui tingkat akurasi diagnosa penyakit skizofernia, schizophrenia merupakan sebuah tampilan psikosa fungsional dengan gangguan utama pada proses pikir serta tidak harmoni (retak, pecah) diantara tahap berfikir, afek atau emosi, keinginan maupun psikomotor yang disertai distorsi kenyataan, terutama karena waham dan halusinasi, asosiasi terbagi-bagi sehingga timbul inkoherensi.

\subsection{Forward Chaining}

Forward chaining pada gambar 2 merupakan strategi penarikan kesimpulan yang di mulai berdasarkan beberapa fakta yang telah diketahui, guna memperoleh sebuah fakta baru dengan menggunakan rule-rule yang mempunyai premis yang cocok dengan fakta dan terus dilanjutkan sampai mendapatkan tujuan atau sampai tidak ada rule yang punya premis yang cocok atau sampai mendapatkan fakta.

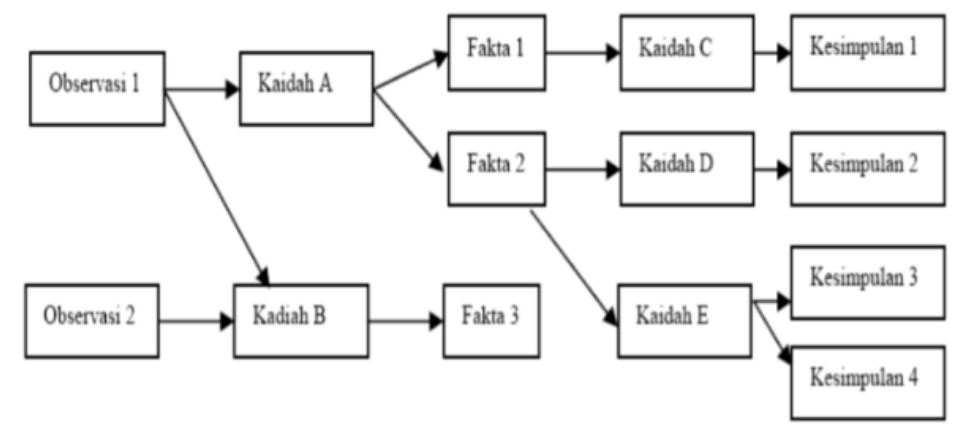

Gambar 2. Proses forward chaining

\subsection{Bayesian Netwok}

Bayesian Network adalah sebuah model grafis hubungan probabilistik antara satu set variable. Bayesian Network terdiri dari dua bagian utarna yaitu struktur grafis untuk menetapkan satu set ketergantungan dan kemandirian hubungan antara variabel dan satu set conditional probability table (CPT) untuk mengukur kekuatan dari hubungan ketergantungan.

$$
P(f \mid a, s, g, j)=\frac{P(f, a, s, g, j)}{P(a, s, g, j)}=\frac{P(f, a, s, g, j)}{\sum_{f} P\left(f^{\prime}, a, s, g, j\right)} .
$$

\section{HASIL DAN PEMBAHASAN}

Kerangka kerja pada penelitian ini meliputi analisa permasalahan, pembentukan basis aturan, penelusuran dengan menggunakan metode forward chaining dan kalkulasi dengan menggunakan bayesian network untuk menghasilkan nilai probabilitas suatu penyakit yang mungkin dialami oleh pasien penderita penyakit skizofrenia.

3.1 Penelusuran forward chaining 
Dari data penyakit dan gejala penyakit gangguan kejiwaan akan didiubah menjadi aturan (rule) yang selanjutnya akan diporses dengan metode forwad chaining untuk melakukan penelusuran keterkaitan data penyakit dengan gejalanya.

Tabel 3. Tabel pakar

\begin{tabular}{cccccccccc}
\hline $\begin{array}{c}\text { Kode } \\
\text { Kode Gejala }\end{array}$ Penyakit & SF1 & SF2 & SF3 & SF4 & SF5 & SF6 & SF7 & SF8 & SF9 \\
\hline GSF1 & $\sqrt{ }$ & $\sqrt{ }$ & $\sqrt{ }$ & $\sqrt{ }$ & $\sqrt{ }$ & $\sqrt{ }$ & $\sqrt{ }$ & $\sqrt{ }$ & $\sqrt{ }$ \\
GSF2 & $\sqrt{ }$ & $\sqrt{ }$ & $\sqrt{ }$ & & $\sqrt{ }$ & $\sqrt{ }$ & $\sqrt{ }$ & $\sqrt{ }$ & \\
GSF3 & $\sqrt{ }$ & $\sqrt{ }$ & $\sqrt{ }$ & $\sqrt{ }$ & $\sqrt{ }$ & & & $\sqrt{ }$ & $\sqrt{ }$ \\
GSF4 & $\sqrt{ }$ & & & $\sqrt{ }$ & & $\sqrt{ }$ & $\sqrt{ }$ & & $\sqrt{ }$ \\
GSF5 & $\sqrt{ }$ & $\sqrt{ }$ & & $\sqrt{ }$ & $\sqrt{ }$ & $\sqrt{ }$ & & $\sqrt{ }$ & \\
GSF6 & $\sqrt{ }$ & $\sqrt{ }$ & & $\sqrt{ }$ & & & $\sqrt{ }$ & & $\sqrt{ }$ \\
GSF7 & $\sqrt{ }$ & $\sqrt{ }$ & & $\sqrt{ }$ & $\sqrt{ }$ & $\sqrt{ }$ & $\sqrt{ }$ & $\sqrt{ }$ & \\
GSF8 & $\sqrt{ }$ & $\sqrt{ }$ & $\sqrt{ }$ & $\sqrt{ }$ & & & $\sqrt{ }$ & & \\
GSF9 & $\sqrt{ }$ & $\sqrt{ }$ & & $\sqrt{ }$ & & $\sqrt{ }$ & $\sqrt{ }$ & & \\
GSF10 & $\sqrt{ }$ & & $\sqrt{ }$ & $\sqrt{ }$ & & $\sqrt{ }$ & & & $\sqrt{ }$ \\
GSF11 & $\sqrt{ }$ & & $\sqrt{ }$ & & & & & & $\sqrt{ }$ \\
GSF12 & $\sqrt{ }$ & $\sqrt{ }$ & & & & $\sqrt{ }$ & & $\sqrt{ }$ & \\
GSF13 & $\sqrt{ }$ & $\sqrt{ }$ & & $\sqrt{ }$ & $\sqrt{ }$ & & & $\sqrt{ }$ & \\
GSF14 & & $\sqrt{ }$ & $\sqrt{ }$ & & & & $\sqrt{ }$ & & \\
GSF15 & & & & & & &
\end{tabular}

3.2 Penelusuran bayesian network

Pada metode bayesian network dilakukan pembobotan untuk mengetahui peluang diagnosa penyakit skizofrenia berdasarkan gejala-gejala yang dialami pasien yang tampak dari tabel 4 hingga tabel 18.

Tabel 4. GSF 1

\begin{tabular}{ccc}
\hline \multirow{2}{*}{ GSF1 } & \multicolumn{2}{c}{ Penyakit Skizofrenia } \\
\cline { 2 - 3 } & Present & Absent \\
\hline Positif (CPT) & 0.86000 & 0.06300 \\
Positif (JPD) & 0.19780 & 0.04851 \\
\hline Posterior Probability & & 0.80305 \\
\hline
\end{tabular}

Tabel 5. GSF 2

\begin{tabular}{ccc}
\hline \multirow{2}{*}{ GSF2 } & \multicolumn{2}{c}{ Penyakit Skizofrenia } \\
\cline { 2 - 3 } & Present & Absent \\
\hline Positif (CPT) & 0.77000 & 0.11000 \\
Positif (JPD) & 0.34650 & 0.06050 \\
\hline Posterior Probability & & 0.85135 \\
\hline
\end{tabular}

Tabel 6. GSF 3

\begin{tabular}{ccc}
\hline \multirow{2}{*}{ GSF3 } & \multicolumn{2}{c}{ Penyakit Skizofrenia } \\
\cline { 2 - 3 } & Present & Absent \\
\hline Positif (CPT) & 0.69000 & 0.04000 \\
Positif (JPD) & 0.28980 & 0.02320 \\
\hline Posterior Probability & & 0.92588 \\
\hline
\end{tabular}


Tabel 7. GSF 4

\begin{tabular}{ccc}
\hline \multirow{2}{*}{ GSF4 } & \multicolumn{2}{c}{ Penyakit Skizofrenia } \\
\cline { 2 - 3 } & Present & Absent \\
\hline Positif (CPT) & 0.66000 & 0.02300 \\
Positif (JPD) & 0.11220 & 0.01909 \\
\hline Posterior Probability & & 0.85460 \\
\hline
\end{tabular}

Tabel 8. GSF 5

\begin{tabular}{ccc}
\hline \multirow{2}{*}{ GSF5 } & \multicolumn{2}{c}{ Penyakit Skizofrenia } \\
\cline { 2 - 3 } & Present & Absent \\
\hline Positif (CPT) & 0.75000 & 0.03200 \\
Positif (JPD) & 0.08250 & 0.02848 \\
\hline Posterior Probability & & 0.74338 \\
\hline
\end{tabular}

Tabel 9. GSF 6

\begin{tabular}{ccc}
\hline \multirow{2}{*}{ GSF6 } & \multicolumn{2}{c}{ Penyakit Skizofrenia } \\
\cline { 2 - 3 } & Present & Absent \\
\hline Positif (CPT) & 0.73000 & 0.01400 \\
Positif (JPD) & 0.29200 & 0.00840 \\
\hline Posterior Probability & & 0.97204 \\
\hline
\end{tabular}

Tabel 10. GSF 7

\begin{tabular}{ccc}
\hline \multirow{2}{*}{ GSF7 } & \multicolumn{2}{c}{ Penyakit Skizofrenia } \\
\cline { 2 - 3 } & Present & Absent \\
\hline Positif (CPT) & 0.78000 & 0.03300 \\
Positif (JPD) & 0.06240 & 0.03036 \\
\hline Posterior Probability & & 0.67270 \\
\hline
\end{tabular}

Tabel 11. GSF 8

\begin{tabular}{ccc}
\hline \multirow{2}{*}{ GSF8 } & \multicolumn{2}{c}{ Penyakit Skizofrenia } \\
\cline { 2 - 3 } & Present & Absent \\
\hline Positif (CPT) & 0.77400 & 0.06370 \\
Positif (JPD) & 0.10062 & 0.05542 \\
\hline Posterior Probability & & 0.64484 \\
\hline
\end{tabular}

Tabel 12. GSF 9

\begin{tabular}{ccc}
\hline \multirow{2}{*}{ GSF9 } & \multicolumn{2}{c}{ Penyakit Skizofrenia } \\
\cline { 2 - 3 } & Present & Absent \\
\hline Positif (CPT) & 0.18000 & 0.01300 \\
Positif (JPD) & 0.11880 & 0.00442 \\
\hline Posterior Probability & & 0.96413 \\
\hline
\end{tabular}

Tabel 13. GSF 10

\begin{tabular}{ccc}
\hline \multirow{2}{*}{ GSF10 } & \multicolumn{2}{c}{ Penyakit Skizofrenia } \\
\cline { 2 - 3 } & Present & Absent \\
\hline Positif (CPT) & 0.22000 & 0.02600 \\
Positif (JPD) & 0.00880 & 0.02496 \\
\hline Posterior Probability & & 0.26066 \\
\hline
\end{tabular}


Tabel 14. GSF 11

\begin{tabular}{ccc}
\hline \multirow{2}{*}{ GSF11 } & \multicolumn{2}{c}{ Penyakit Skizofrenia } \\
\cline { 2 - 3 } & Present & Absent \\
\hline Positif (CPT) & 0.55310 & 0.02170 \\
Positif (JPD) & 0.03872 & 0.02018 \\
\hline Posterior Probability & & 0.64923 \\
\hline
\end{tabular}

Tabel 15. GSF 12

\begin{tabular}{ccc}
\hline \multirow{2}{*}{ GSF12 } & \multicolumn{2}{c}{ Penyakit Skizofrenia } \\
\cline { 2 - 3 } & Present & Absent \\
\hline Positif (CPT) & 0.34800 & 0.01030 \\
Positif (JPD) & 0.15660 & 0.00567 \\
\hline Posterior Probability & & 0.96509 \\
\hline
\end{tabular}

Tabel 16. GSF 13

\begin{tabular}{ccc}
\hline \multirow{2}{*}{ GSF13 } & \multicolumn{2}{c}{ Penyakit Skizofrenia } \\
\cline { 2 - 3 } & Present & Absent \\
\hline Positif (CPT) & 0.61240 & 0.00930 \\
Positif (JPD) & 0.04287 & 0.00865 \\
\hline Posterior Probability & & 0.83211 \\
\hline
\end{tabular}

Tabel 17. GSF 14

\begin{tabular}{ccc}
\hline \multirow{2}{*}{ GSF14 } & \multicolumn{2}{c}{ Penyakit Skizofrenia } \\
\cline { 2 - 3 } & Present & Absent \\
\hline Positif (CPT) & 0.88700 & 0.01200 \\
Positif (JPD) & 0.05322 & 0.01128 \\
\hline Posterior Probability & & 0.82512 \\
\hline
\end{tabular}

Tabel 18. GSF 15

\begin{tabular}{ccc}
\hline \multirow{2}{*}{ GSF15 } & \multicolumn{2}{c}{ Penyakit Skizofrenia } \\
\cline { 2 - 3 } & Present & Absent \\
\hline Positif (CPT) & 0.64120 & 0.03990 \\
Positif (JPD) & 0.01924 & 0.03870 \\
Posterior Probability & & 0.33200 \\
\hline
\end{tabular}

\subsection{Pengujian}

Pada pengujian ini diberikan beberapa gejala yang dialami oleh pasien :

1. Hilang nafsu makan.

2. Berat badan naik atau turun tanpa di sengaja.

3. Perubahan kebiasaan tidur.

4. Gelisah.

5. Hilang energi.

6. Kesulitan berfikir atau konsentrasi.

7. Bicara lebih cepat dan cerewet.

Berdasarkan gejala tersebut tampak mengarah ke skizofrenia disorder. Guna mengetahui pasien menderita penyakit skizofrenia disorder maka dilakukan penghitungan bayesian network seperti berikut: 
$0.80305+0.85135+0.92588+0.85460$

$+0.74338+0.96413+0.96509=0.87249714$

Jadi kemungkinan pasien menderita gejala skizofrenia disorder sebesar 0.87249714 atau $87 \%$

\subsection{Use Case diagram}

Dalam sistem pakar diagnosa penyakit skizofrenia, user hanya konsultasi mengenai gejala penyakit skizofrenia. Sedangkan untuk admin yang mengelola sistem pakar diagnosa penyakit skizofrenia harus login terlebih dahulu untuk mengelola beberapa menu.

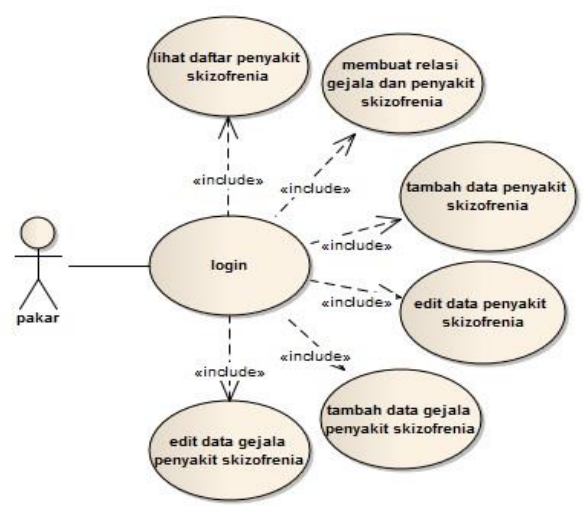

Gambar 3. Use Case Diagram Pakar

\subsection{Activity Diagram}

Activity Diagram menggambarkan berbagai alur dalam sistem yang sedang dirancang.

a) Activity Diagram User Konsultasi

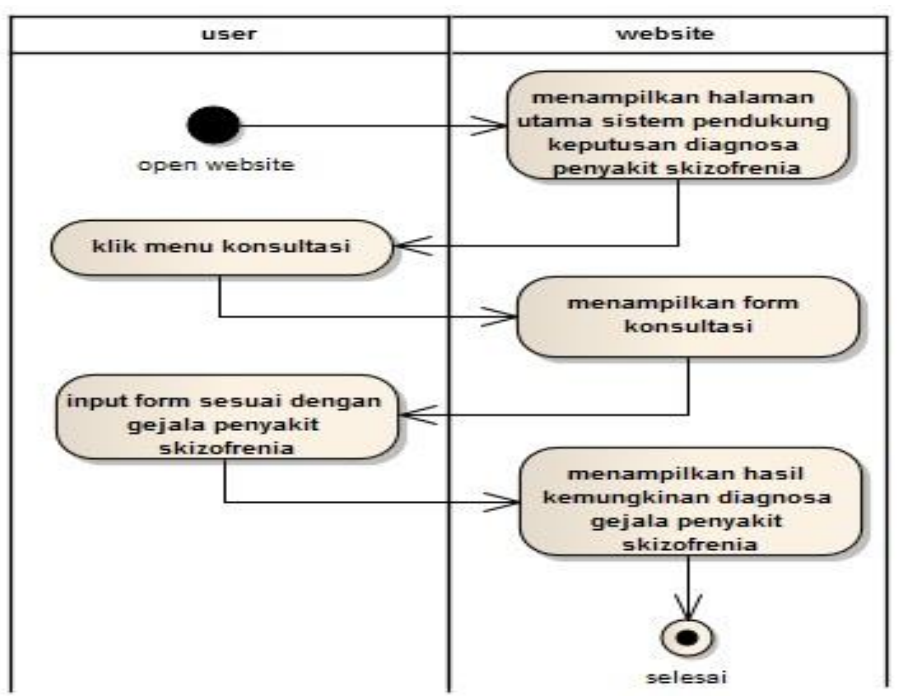

Gambar 4. Activity Diagram User Konsultasi

b) Activity Diagram Login Pakar 


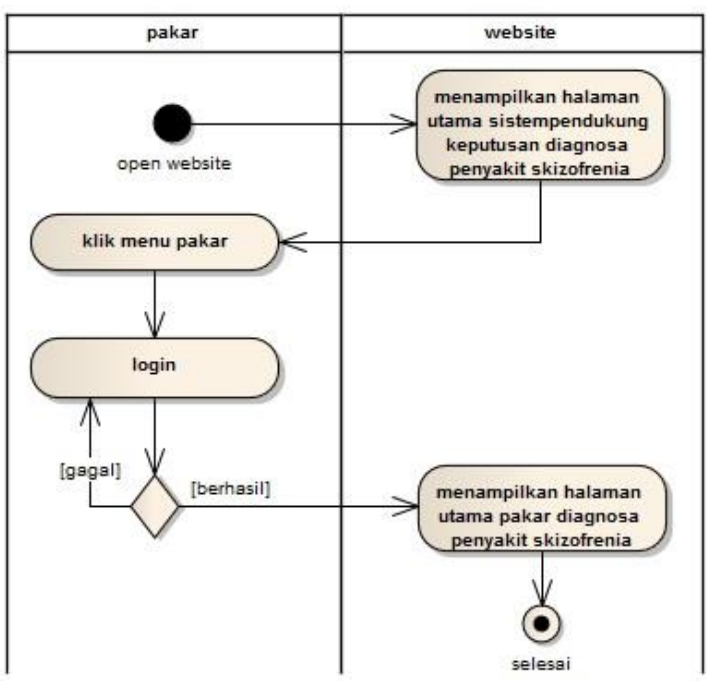

Gambar 5. Activity Diagram Login Pakar

\subsection{Implementasi Sistem}

Implementasi sistem pada penelitian dirancang dan dibangun menggunakan Bahasa pemrograman PHP berbasis website dan menggunakan database MySQL.:

\section{1) Menu Prediksi}

Berikut pada gambar 6 merupkan tampilan awal pada saat sistem pakar ini dimulai.

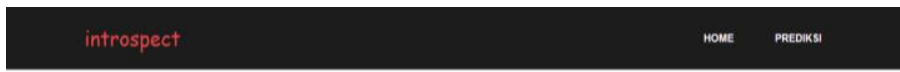

SISTEM PAKAR ALGORITMA FORWARD CHAINING DAN BAYESIAN NETWORK

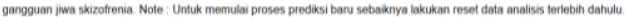

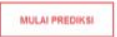

Gambar 6. Home User

2) Menu Prediksi

\section{introspect howe pereonsi resert}

APLIKASI BANTU DIAGNOSA PENYAKIT

APAKAH HILANG NAFSU MAKAN[ G001] ?

( benar (a)

SALAH (TIOAK)

Gambar 7. Menu Prediksi

Dalam gambar menampilkan menu untuk megetahui gejala-gejala yang akan diprediksi. 
3) Hasil Diagnosa
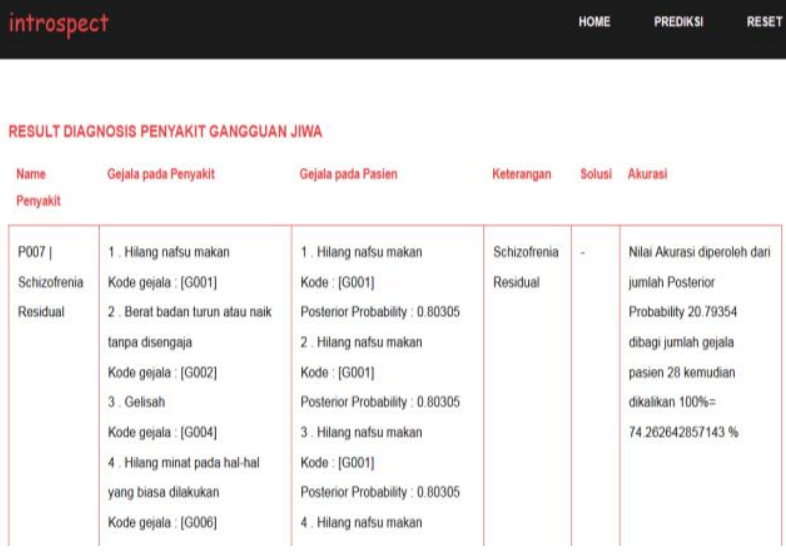

Gambar 8. Hasil Diagnosa

Gambar 8 merupakan hasi dari diagnosa diagnose yang sudah diinputkan sebelumnya dari sistem pakar.

4) Menu Pakar

Gambar 9 merupakan tampilan awal login sebelum masuk kedalam sistem pakar.

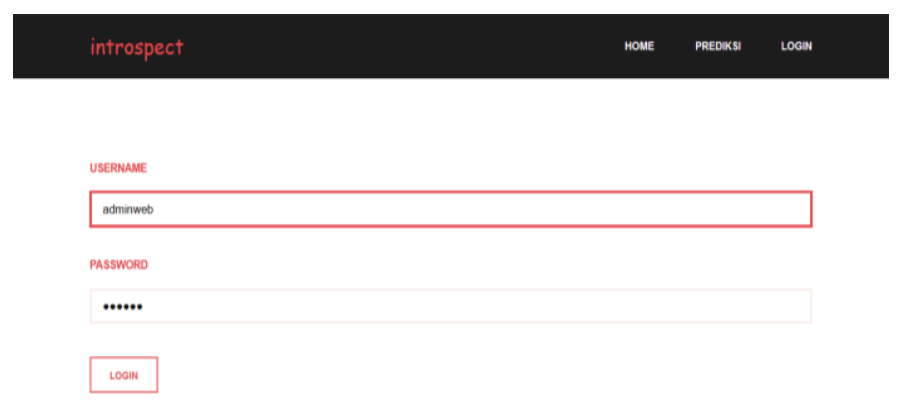

Gambar 9. Login Pakar

\section{KESIMPULAN}

Sistem Pakar ini berfungsi untuk membantu dalam mendiagnosis penyakit skizofrenia, agar dapat diketahui secara dini. Sistem Pakar ini menggunakan metode Forward Chaining dan Algoritma Bayesian Network guna mendiagnosa penyakit skizofrenia. Sistem Pakar ini mendiagnosa penyakit skizofrenia berdasarkan dari gejala-gejala yang dialami oleh pasien. Dari proses penghitungan nilai akurasi untuk pasien menderita penyakit skizofrenia disorder menggunakan bayesian network dihasilkan nilai akurasi prediksi sebesar $87 \%$.

\section{SARAN}

Sistem Pakar Diagnosa Penyakit Skizofrenia menggunakan Forward Chaining dan Bayesian Network ini dapat dikembangkan lebih lanjut dalam bentuk berbasis android. Sistem Pakar Diagnosa Penyakit Skizofrenia dapat dikembangkan dengan menggunakan metode atau algoritma lainnya. 


\section{DAFTAR PUSTAKA}

[1] Kementrian Kesehatan Republik Indonesia, 2016, Peran Keluarga Dukung Kesehatan Jiwa Masyarakat, Jakarta.

[2] Riyadi, Sujono dan Teguh, Purwanto, 2013, Asuhan Keperawatan Jiwa, Graha Ilmu, Yogyakarta.

[3] Keliat, B.A da Akemat, 2012, Model Praktik Keperawatan Profesional Jiwa, EGC, Jakarta.

[4] Yosep, Iyus, 2014, Buku Ajar Keperawatan Jiwa, Refika Aditama, Bandung.

[5] Maslim, Rusdi, 2013, Diagnosis Gangguan Jiwa (Rujukan Ringkas dari PPDGJIII dan DSM5), Unika Atmajaya, Jakarta.

[6] Davison, Gerald C., Neale, John dan Kring, Ann, 2012, Psikologi Abnormal edisi ke-9, Raja Grafindo, Jakarta.

[7] Kaplan, Harold., Sadock, Benjamin dan Grebb, Jack, 2010, Sinopsis Psikiatri, Binarupa Aksara, Jakarta.

[8] Direja, Ade Herma, 2011, Asuhan Keperawatan Jiwa, Nuha Medika, Yogyakarta.

[9] Bambang Eko, 2016, Peran Keluarga Dukung Kesehatan Jiwa Masyarakat, Artikel Kementrian Kesehatan Republik Indonesia, Jakarta.

[10] Muzakir, Muhammad, 2017, Implementasi Algoritma Neuro-Fuzzy untuk Diagnosa Penyakit Skizofrenia, Jurnal Elektronik Nasional Teknologi dan Ilmu Komputer, Universitas Lambung Mangkurat, Banjarmasin.

[11] Sudarmana,Landung,2018, Aplikasi Sistem Pakar untuk Mendiagnosis Gangguan Jiwa Schizophrenia, Jurnal Informatika, STMIK Jenderal Achmad Yani, Yogyakarta.

[12] Nugroho, Bunafit, 2012, Aplikasi Sistem Pakar, Gava Media, Yogyakarta.

[13] Kurniawan, Dwi Cahyono, 2016, Sistem Pakar untuk Mendiagnosa Penyakit Skizofrenia dengan Metode Forward Chaining, Publikasi Ilmiah, Universitas Muhammadiyah, Surakarta.

[14] Wardhani, Rima Diah, 2017, Sistem Pakar Diagnosis Penyakit Schizophrenia menggunakan Metode Bayesian Network, Jurnal Pengembangan Teknologi Informasi dan Ilmu Komputer, Universitas Brawijaya, Malang.

[15] Mona, Aldino Motu, 2012, Studi Perbandingan Metode Fuzzy dan Certainty Factor dalam Mendiagnosa Penyakit Skizofrenia, STMIK GI MDP, Palembang. 